\title{
Bertani Padi Bagi Orang Melayu Sambas: Kearifan Lokal, Nilai- Nilai Islam, dan Character Building
}

\author{
Syamsul Kurniawan \\ IAIN Pontianak \\ Syamsulkurniawan001@gmail.com \\ Bayu Suratman \\ UIN Sunan Kalijaga Yogyakarta \\ bayuseladu@gmail.com
}

Abstract: $\quad$ Farming is the local wisdom of the Sambas Malays, which has a very strategic role in building character, especially for farmers. The values in the local "farming" wisdom adopted by the Sambas Malays will be an identity for them, their mark as Muslims and part of a community of dignified Malays. This is in line with opinion of Hermansyah (2015), who calls Melayu is identic with Islam. The focus of this article is how the Sambas Malays builds character through farming with various representative forms. The article departed from qualitative study in which the data was obtained from observation and indepth interview at the research site, acquired conclusion that farming builds Islamic values in the Sambas Malays such as work ethic, responsibility, helping each other, sincerity, patience, generosity and caring.

Abstrak: Bertani padi merupakan kearifan lokal orang Melayu Sambas, yang mempunyai peran sangat strategis dalam membangun karakter, khususnya bagi petani padi, mengandung nilai-nilai Islam. Nilai-nilai dalam kearifan lokal bertani padi yang dianut oleh orang Melayu Sambas akan menjadi identitas bagi mereka, penanda mereka sebagai orang Islam dan bagian dari komunitas orang Melayu yang bermartabat. Hal ini sejalan dengan dengan pendapat Hermansyah (2015), yang menyebut 
Melayu identik dengan Islam. Fokus artikel ini adalah tentang bagaimana orang Melayu Sambas melalui bertani padi dengan berbagai bentuk kearifan lokal yang menyertainya, mengandung sejumlah nilai-nilai Islam yang representatif untuk membangun karakter. Artikel ini yang berangkat dari sebuah penelitian kualitatif, di mana data-datanya diperoleh dari pengamatan dan wawancara mendalam di lokasi penelitian, memperoleh simpulan bahwa bertani padi membangun nilai-nilai Islam pada orang Melayu Sambas seperti etos kerja, tanggung jawab, tolong menolong, ikhlas, sabar, kedermawanan, dan kepedulian.

Kata kunci: farming, local wisdom, Islamic values

\section{A. Pendahuluan}

Membangun karakter (character building) merupakan proses yang memberikan dampak positif terhadap perkembangan emosional, spiritualitas, dan moralitas seseorang. Bagi bangsa ini, membangun karakter merupakan bagian penting dalam membangun jati diri sebuah bangsa. Bangsa ini sudah sepatutnya untuk kembali kepada jati diri mereka melalui pemaknaan kembali dan rekonstruksi nilainilai luhur dalam kearifan lokal mereka. Dalam kerangka itu, upaya yang perlu dilakukan adalah menguak makna substantif kearifan lokal.

Kearifan lokal dapat dipahami sebagai gagasan-gagasan, nilai-nilai, pandangan-pandangan setempat (local) yang bersifat bijaksana, penuh kearifan, bernilai baik, yang tertanam dan diikuti oleh anggota masyarakatnya. ${ }^{1}$ Kearifan lokal merupakan salah satu produk budaya. Hal mana pada budaya dalam pengertian ini dimaknai sebagai sistem simbol bersama, keyakinan, dan praktik yang diciptakan oleh sekelompok orang sebagai mekanisme adaptif untuk kelangsungan hidup dan perkembangan mereka dan kemudian ditransmisikan kepada generasi berikutnya sebagai bagian dari

${ }^{1}$ Hatamar Rasyid, "Nilai-Nilai Kearifan Lokal Dalam Pengembangan Pendidikan Karakter Di Era Global,” Edugama 1, no. 1 (2015): 25. 
pengetahuan mereka. ${ }^{2}$ Sebagai sebuah produk budaya kearifan lokal dapat menjadi identitas komunitas masyarakat yang membedakannya dengan komunitas masyarakat lainnya. Karena itu, hampir bisa dipastikan pada setiap komunitas pastilah memiliki identitas etnis yang khas sesuai dengan karakteristik masing-masing.

Orang Melayu Sambas memiliki tata aturan atau norma yang khas dalam bermasyarakat, berupa kearifan lokal yang sejak dulu sudah ada dan dipertahankan oleh mereka sampai sekarang. Kearifan lokal orang Melayu Sambas, di sini berupa sekumpulan tata nilai dan sistem perilaku orang Melayu Sambas dalam berinteraksi dengan lingkungan sekitar dengan arif. Kearifan lokal di sini dapat berbentuk semua pengetahuan, pemahaman atau keyakinan, dan bahkan adat istiadat dan etika yang mengatur bagaimana individu dan kelompok bagi mereka yang mengidentifikasi diri sebagai orang Melayu Sambas.

Kearifan lokal orang melayu Sambas yang berupa gagasangagasan setempat yang bersikap bijaksana, penuh kearifan, bernilai baik yang tertanam dan diikuti, hakikatnya dapat membangun karakter, termasuk membangun karakter mereka sebagai muslim. Hal ini sesungguhnya mudah dipahami, mengingat manusia dalam kehidupannya, sulit untuk lepas dari pengaruh ajaran agama yang mereka anut. Namun karena manusia juga sebagai makhluk sosial, sehingga pengaruh tradisi lokal dan atau adat budaya tempat mereka tinggal, pada gilirannya mewarnai perjalanan kehidupannya dari masa ke masa yang melembaga dalam kearifan lokal mereka, sebagai ujud dari persentuhan yang kita sebut dengan akulturasi.

Menurut Koentjaraningrat, akulturasi itu sendiri muncul bila suatu kelompok masyarakat dengan suatu kearifan lokal tertentu dihadapkan dengan unsur-unsur asing yang berbeda, unsur-unsur asing itu lambat laun diterima dan diolah ke dalam kearifan lokal sendiri tanpa menyebabkan hilangnya kepribadian kearifan lokal itu

${ }^{2}$ Asuncion-Lande, N.C. 1990. "Intercultural Communication", in Gordon L. Dahnke and Glen W. Clatterbuck, eds., Human Communication: Theory and Research (Belmont, Calif: Wadsworth Pub. Co, 1990), 23. 
sendiri. ${ }^{3}$ Pada saat nilai agama bersentuhan dengan kearifan lokal, maka bisa terjadi kesesuaian, atau tidak menutup kemungkinan yang terjadi sebaliknya, saling berbenturan satu sama yang lain, walau pada kasus ini sangat jarang terjadi.

Bertani padi adalah salah satu bentuk kearifan lokal orang Melayu Sambas, yang dekat dengan nilai-nilai Islam, dianggap mempunyai peran sangat strategis dalam membangun karakter mereka sebagai orang Melayu dan sekaligus sebagai muslim, khususnya bagi petani padi. Nilai-nilai dalam kearifan lokal bertani padi yang dianut oleh orang Melayu Sambas akan menjadi identitas bagi mereka, penanda mereka sebagai bagian dari orang Melayu yang bermartabat dan muslim yang taat. Hal ini sejalan dengan dengan pendapat Hermansyah, yang menyebut Melayu identik dengan Islam, dan dengan demikian pada kearifan lokal mereka sangat dekat dengan Islam. ${ }^{4}$

Di Sambas, bertani padi dilakukan secara tradisional. Ketradisionalan ini, nampak dari kebiasaan-kebiasaan bertani padi oleh orang Melayu Sambas dan telah berlangsung sangat lama serta turun-temurun. Keberlangsungan bertani padi yang mencerminkan kearifan lokal orang Melayu Sambas, tercermin dari nilai-nilai yang berlaku dalam kelompok mereka. Nilai-nilai itu menjadi pegangan mereka, dan menjadi bagian dari kehidupan yang tak terpisahkan, baik sikap atau perilaku mereka sehari-hari.

Tidak banyak tulisan hasil penelitian, yang membahas bertani padi pada orang Melayu Sambas. Sejauh penelusuran penelitian yang peneliti lakukan, sebuah artikel penelitian yang membahas ini ditulis oleh Wewen Darmawan, Amrazi Zakso, dan Gusti Budjang, memudarnya nilai-nilai budaya belalek dalam bidang pertanian pada masyarakat perdesaan. Hasil penelitian menunjukkan bahwa nilai-nilai budaya belalek seperti kerjasama, solidaritas maupun

${ }^{3}$ Koentjaraningrat, Pengantar Antropologi (Jakarta: Aksara Baru, 1974), 152. Press, 2015).

${ }^{4}$ Hermansyah, Islam Dan Melayu Di Borneo (Pontianak: IAIN Pontianak 
material sudah mulai jarang dilakukan lagi sehingga memunculkan sistem upah yang menggeser budaya belalek. ${ }^{5}$

Fokus artikel ini adalah tentang bagaimana orang Melayu Sambas melalui bertani padi dengan berbagai bentuk kearifan lokal yang menyertainya, mengandung sejumlah nilai-nilai Islam yang representatif untuk membangun karakter. Fokus artikel ini dengan demikian tidak sama dengan fokus artikel hasil penelitian di atas. Fokus ini selanjutnya dijabarkan pada sejumlah pertanyaan: pertama, bagaimana bertani padi dikerjakan oleh orang Melayu Sambas?; kedua, apa bentuk-bentuk kearifan lokal dari bertani padi yang dikerjakan oleh orang Melayu Sambas?; ketiga, nilai-nilai Islam apa saja yang tercermin dalam bertani padi beserta kearifan lokalnya? mengapa bertani padi beserta kearifan lokalnya dapat membangun karakter?.

Artikel yang berangkat dari sebuah penelitian kualitatif ini, di mana data-datanya diperoleh dari pengamatan dan wawancara mendalam di lokasi penelitian. Penelitian ini di lakukan di Sambas, khususnya di daerah Sebawi, Sambas, Tebas, Semparuk, Pemangkat, Selakau dan Salatiga. Tempat di mana bertani padi ini masih banyak dikerjakan.

\section{B. Gambaran Tentang Sambas Dan Orang Melayu Sambas}

Kabupaten Sambas secara administratif merupakan sebuah kabupaten yang terletak di Propinsi Kalimantan Barat. Luas wilayah Kabupaten Sambas mencapai 6.395, $70 \mathrm{~km}^{2}$ atau sekitar 639.570 ha. Dengan demikian luas wilayah kabuapten Sambas diperkirakan 4,36\% dari total luas daerah Propinsi Kalimantan Barat. Kabupaten Sambas terletak di bagian pantai barat paling utara dari Propinsi Kalimantan Barat.

Secara geografis Kabupaten Sambas terletak antara $1^{0} 23^{00}$ dan $108^{0} 39^{00}$ Bujur Timur, yang berbatasan dengan Sarawak (Malaysia Timur) di sebelah utara; Kota Singkawang dan Kabupaten

${ }^{5}$ Wewen Darmawan, Amrazi Zakso, Gusti Budjang, "Memudarnya NilaiNilai Budaya 'Belalek' Dalam Bidang Pertanian Pada Masyarakat Pedesaan," Jurnal Pendidikan Dan Pembelajaran 5, no. 3 (2016): 1-14. 
Bengkayang di sebelah selatan; Selat Karimata dan Laut Cina Selatan di sebelah barat; dan Kabupaten Bengkayang dan Sarawak (Malaysia Timur) di sebelah timur. Secara historis, Kabupaten Sambas yang ada saat ini, merupakan pemekaran dari kabupaten pada tahun 2000. Sebelumnya wilayah Kabupaten Sambas sangat luas, di mana meliputi Kota Singkawang dan Kabupaten Bengkayang sejak tahun 1960. Hakikatnya Kabupaten Sambas merupakan daerah yang punya akar historis kuat dengan kekuasaan kesultanan Sambas.

Gambar 1. Peta Sambas ${ }^{6}$

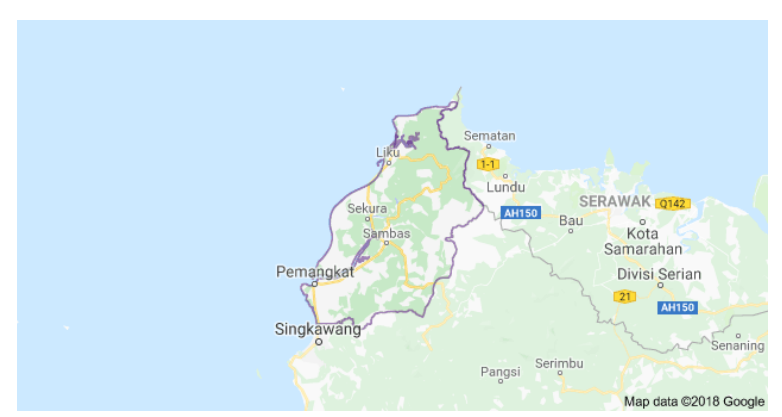

Penduduk di Kabupaten Sambas diperkirakan mencapai 523.115, dengan perincian 258.475 laki-laki dan 264.640 perempuan $^{7}$. Secara umum penduduk Sambas adalah orang Melayu, yang menjalani keseharian dan tradisi sebagai orang Melayu Sambas. Sisanya berlatar belakang etnis Dayak, Tionghua, dan etnis lain. Mayoritas orang Melayu Sambas beragama Islam.

Kaitannya dengan ini, di Sambas terdapat kaitan yang jelas antara identitas mereka sebagai orang Melayu dan agama yang mereka anut yaitu Islam. Sebagaimana telah diungkap di muka, menurut Hermansyah, Melayu identik dengan Islam. ${ }^{8}$ Menurut teori ini, Islam merupakan penanda identitas kemelayuan seseorang. Dapat

6 "Peta Kabupaten Sambas Kalimantan Barat," 2018, https://www.google.com/maps/place/Kabupaten+Sambas,+Kalimantan+Barat/@ 1.4 876623,108.7686435,9z/data=!3m1!4b1!4m5!3m4!1s0x31e4c6f5a0740299:0x6c63 ef7cfcd2b27c!8m2!3d1.3625191!4d109.2831531.

${ }^{7}$ Badan Pusat Statistik Kabupaten Sambas, "Publikasi Statistik," Badan Pusat Statistik Kabupaten Sambas (blog), 2018, https://sambaskab.bps.go.id/.

${ }^{8}$ Hermansyah, Islam Dan Melayu Di Borneo, 1. 
pula dikatakan, orang Melayu adalah identitas untuk menyebut masyarakat yang beragama Islam yang masih menjalankan tradisi atau adat-istiadat Melayu Sambas dalam keseharian mereka. Dari aspek bahasa, orang Melayu Sambas menggunakan bahasa Melayu Sambas dalam bertutur, sebagaimana seumumnya masyarakat Melayu.

Sejauh pengamatan peneliti, orang Melayu Sambas memiliki hubungan emosional yang kuat dengan sesama orang Melayu Sambas. Hal ini wajar saja, mengingat orang Melayu yang merupakan sebuah kelompok di masyarakat, yang hakikatnya merupakan kumpulan dari individu-individu yang bersepaham untuk hidup bersama, entah atas dasar kepentingan-kepentingan bersama atau dasar faktor-faktor ideologis. ${ }^{9}$

Pekerjaan orang Melayu Sambas secara umum dapat dikatakan bervariasi, dan salah satunya adalah bertani padi. Di sebagian tempat di Sambas, orang Melayu Sambas memang bergantung pada sawah atau kebun, terutama padi untuk menopang perekonomian keluarga.

\section{Bertani Padi di Sambas}

Orang Melayu dari suku Melayu Sambas dikenal mempunyai etos kerja yang tinggi. Demikian pula mereka yang bertani padi. Secara ekonomis ini berdampak positif bagi pertumbuhan ekonomi masyarakat. Bahkan, bisa dikatakan bahwa Kabupaten Sambas saat ini, setidaknya dalam tiga tahun terakhir, merupakan lumbung padi Kalimantan Barat. Pada tahun 2015, luas tanam di Sambas sekitar 108,570 Ha dengan jumlah produksi padi sebesar 286,501 ton. ${ }^{10}$ Teranyar diberitakan, luas sawah di Sambas potensi hasilkan 169.465 ton padi. ${ }^{11}$

${ }^{9}$ Syarifuddin Jurdi, Sosiologi Islam Elaborasi Pemikiran Sosial Ibn Khaldun. (Yogyakarta: Sukses Offset, 2008), 189.

10 Hamdan Darsani, "Hairiah: Sambas Merupakan Lumbung Beras Kalbar," Tribun Pontianak, September 19, 2016.

${ }^{11}$ Fah, "Luas Sawah Di Sambas Potensi Hasilkan 169.465 Ton Padi," Pontianak Post, Pebruari 2018. 
Asal usul orang Melayu Sambas bertani padi peneliti peroleh dari informasi lisan dari orang Melayu di Sambas. Dulunya, orang Melayu Sambas hidup di tepian sungai. Lambat laun mereka mulai berpikir untuk membuka lahan pertanian, seperti orang-orang Melayu yang sebelumnya bermukim di tepi Sungai Tapah dan hulu Sambas yang kemudian berpindah mukim ke daerah Seburing dan Sepadu untuk membuka lahan pertanian. Alat transportasi saat itu masih menggunakan transportasi air yaitu sampan atau perahu. ${ }^{12}$

Sistem pertanian di Sambas saat ini masih dikelola secara tradisional, meskipun sebagian sudah ada yang menggunakan alatalat bertani yang lebih modern. Berdasarkan pengamatan dan wawancara peneliti dengan masyarakat setempat, bertani padi di Sambas memerlukan waktu berkisar 4 bulan atau 5 bulan, dari awal membuka lahan sampai panen. Untuk tahap yang pertama dimulai dari bumme atau membuka lahan. Membuka lahan yang dimaksud di sini, bukan membuka lahan pertanian baru, melainkan memulai awal proses bertani dari masa sesudah panen. Bumme bisa juga diartikan membersihkan lahan dari batang padi selesai panen. ${ }^{13}$

Bumme biasanya dilakukan dengan menebas sisa batang padi atau dengan cara menumbangkan batang padi. Menebas batang padi dibantu dengan menggunakan parang. Jika padi ditumbangkan masyarakat biasanya membuat alat dari papan dan kayu sehingga berbentuk huruf U. Setelah itu padi dinjak-injak dengan menggunakan alat yang telah dibuat. Selain dengan membuat alat tersebut biasanya masyarakat menggunaka drum bekas. Pada prinsipnya membersihkan lahan ini atau memulai pertanian sebelumnya harus dibersihkan secara tuntas. Sehingga bagi masyarakat hasil pertanian akan bagus. ${ }^{14}$

Setelah lahan siap untuk ditanami padi selanjutnya petani memulai menanam padi atau mereka sebut dengan nandor, yang

${ }^{12}$ Berdasarkan informasi dari hasil wawancara dengan bapak Rusdi dan Bapak Rabuli, orang Melayu Sambas, 23 Juli 2018.

${ }^{13}$ Berdasarkan informasi dari hasil wawancara dengan Bapak Hamid, Ibu Susi, dan Ibu Naimah orang Melayu Sambas, 21-22 Juli 2018 di Sambas.

${ }^{14}$ Berdasarkan informasi dari hasil wawancara dengan dengan Bapak Hamid, Ibu Susi dan ibu Naimah orang Melayu Sambas, 21-22 Juli 2018 di Sambas. 
biasanya dilaksanakan setelah turun hujan. Asumsinya, tanah tidak kering, sehingga memudahkan masyarakat dalam melaksanakan kegiatan nandor. Selain menunggu curah hujan masyarakat juga memperhatikan usia semaian padi atau dalam bahasa Sambas camaian. Camaian adalah anak padi yang ditanam dalam proses incamai. Proses incamai akan peneliti sebutkan dalam tahapan panen dikarenakan incamai akan dilaksanakan dalam proses panen. ${ }^{15}$

Nandor harus dilaksanakan secara berpasang-pasangan. Untuk saat ini proses nandor dalam bertani masyarakat Sambas masih menggunakan cara tradisional. Biasanya dalam kegiatan nandor dilakukan oleh laki-laki dan perempuan. Pekerjaan bagi lakilaki ialah nugal atau membuat lubang sedangkan bagi yang perempuan memasukan semaian padi ke dalam lubang tersebut. Untuk alat dalam proses nandor disebut tugal. Untuk membuat tugal dibuat dari batang kayu dan bagian ujung kayu tersebut dibuat lancip. Proses nandor paling sulit dan memerlukan waktu yang lama bagi masyarakat. Karena dalam proses nandor memerlukan keahlian khusus serta kesabaran karena dalam membuat lubang bagi yang laki-laki harus berjalan ke belakang. Jarak lubang satu dengan yang lain harus sama sehingga lubang tersebut beraturan. Bagi yang perempuan harus mengisi lubang dengan cara menunduk hal ini diperlukan kesabaran dan ketelitian. Dikarenakan dalam mengisi semaian padi seorang perempuan harus menghindari lubang yang dibuat agar tidak terinjak. Selain itu juga diperlukan keserasian dalam nandor. Salah satu faktor yang dipercaya menentukan kualitas pertumbuhan padi ialah tahap dalam pekerjaan nandor, dikarenakan akar semaian padi harus tersentuh ke dalam tanah. Keserasian antara penugal dan pengisi semaian padi juga harus diperhatikan. Jika tidak ada keserasian dan keseimbangan maka lubang akan rusak karena diinjak pengisi semaian. Begitupula jika penugal tidak seimbang antara mengisi lubang dengan berjalan maka membuat lubang yang dibuat tidak akan bisa tumbuh semaian padi.

${ }^{15}$ Berdasarkan informasi dari hasil wawancara dengan Bapak Hamid, Ibu Susi dan ibu Naimah orang Melayu Sambas, 21-22 Juli 2018 di Sambas. 
Setelah melaksanakan pekerjaan nandor masyarakat melakukan pekerjaan memupuk padi. Memupuk padi biasanya masyarakat lakukan 2-3 minggu setelah melakukan kegiatan nandor. Dalam memupuk padi juga diperlukan kesabaran karena dalam memupuk tidak boleh sembarang melempar pupuk, karena harus mengenai akar padi. Tidak jarang petani yang memupuk padi dengan cara memupuk satu persatu dari batang padi, yang dalam istilah orang Melayu Sambas disebut dengan rapun. Walaupun dari segi waktu lebih lama namun bagi orang Melayu Sambas, pekerjaan memupuk satu persatu dari batang padi sangat baik untuk pertumbuhan padi. Untuk batang padi masyarakat Sambas menyebutnya dengan istilah rapun. ${ }^{16}$

Tahapan selanjutnya setelah melakukan pemupukan terhadap padi, petani melakukan perawatan padi dari hama dan gulma. Untuk membersihkan hama yang petani lakukan adalah menyemprotkan obat pembunuh hama. Sedangkan untuk pembasmian gulma, petani Melayu Sambas masih melakukannya secara tradisional dengan cara merumput. Merumput artinya membersihkan rumput dari tanaman padi. Rumput di sini dianggap sebagai gulma atau tanaman yang menganggu pertumbuhan padi. Merumput memerlukan waktu yang cukup dan memerlukan tenaga yang ekstra. Karena dalam proses merumput seorang petani harus membungkukkan badan. Selain itu, berjalan mesti hati-hati, karena jika salah sedikit saja, ada kemungkinan padi akan terinjak. ${ }^{17}$

Tahapan terakhir yang paling ditunggu-tunggu oleh petani Melayu Sambas adalah masa panen atau dalam istilah Sambas disebut beranyi. Beranyi bagi orang Melayu Sambas merupakan momen yang paling ditunggu. Memanen padi, tidak boleh ditundatunda, karena seperti dijelaskan oleh informan penelitian ini, kuantitas padi yag dipanen bisa berkurang dikarenakan hama seperti, tikus, burung pipit, bahkan ayam. Beranyi dilakukan orang Melayu Sambas dengan mengikuti tahapan sebagai berikut: pertama, dengan

${ }^{16}$ Berdasarkan informasi dari hasil wawancara dengan Bapak Hamid, Ibu Susi dan ibu Naimah, orang Melayu Sambas, 21-22 Juli 2018 di Sambas.

${ }^{17}$ Berdasarkan informasi dari hasil wawancara dengan Bapak Hamid, Ibu Susi dan ibu Naimah, orang Melayu Sambas, 21-22 Juli 2018 di Sambas. 
cara menggunakan kattam atau pengetam. Meski terkesan tradisional, namun sampai saat ini cara tersebut masih banyak digunakan oleh petani Melayu Sambas. Mengatam padi dilakukan dengan cara memisahkan padi dari tangkai padi atau sebagian menyebutnya dituai; kedua, dengan cara menggunakan pengampok yaitu dengan memukulkan batang padi sehingga padi terpisah dari tangkai. ${ }^{18}$

\section{Kearifan Lokal Dalam Bertani Padi Orang Melayu Sambas}

Berikut peneliti deskripsikan kearifan lokal-kearifan lokal dalam bertani padi orang Melayu Sambas:

Ngamping

Kearifan lokal merupakan kebiasaan yang biasanya terkristalisasikan dalam berbagai ritual/tradisi yang diselenggarakan pada momen-momen tertentu, ${ }^{19}$ seperti ngamping. Ngamping berarti membuat amping, yaitu makanan yang terbuat dari biji padi yang setengah matang yang dimasak dengan cara diaruk atau dioseng dalam wajan sampai biji padi tersebut mengeluarkan bunyi. Setelah itu biji padi yang telah di aruk dimasukan dalam lesung yang terbuat dari kayu dan ditumbuk sampai berbentuk pipih. Setelah ditumbuk biji padi tersebut dibersihkan menggunakan nyirrok atau diampik agar ampas dari kulit biji padi terbuang. Pengambilan beras setengah masak untuk dibuat amping ini sekaligus untuk mengawali musim panen padi, ekspresi dari rasa syukur atas hasil panen padi, serta pemanjatan doa bersama agar musim beranyi selalu diberikan karunia dari Tuhan yang Maha Esa, ${ }^{20}$ sehingga mendapatkan hasil panen yang menggembirakan. ${ }^{21}$

${ }^{18}$ Berdasarkan informasi dari hasil wawancara dengan Bapak Hamid, Ibu Susi dan ibu Naimah, orang Melayu Sambas, 21-22 Juli 2018 di Sambas.

${ }^{19}$ Rizal Mustansyir, Kearifan Lokal Masyarakat Melayu Sambas Dalam Tinjauan Filosofis (Yogyakarta: Fakultas Filsafat UGM, 2015), 133.

${ }^{20}$ Berdasarkan informasi dari hasil wawancara dengan Bapak Ramlan dan ibu Maniah, orang Melayu Sambas, 19 Juli 2018 di Sambas.

${ }^{21}$ Syamsul Kurniawan, ed., "Tradisi Ngamping Orang Melayu Sambas Desa Sebayan," in Tradisi dan Kepercayaan Umat Islam di Kalimantan Barat, 1 (Yogyakarta: Samudera Biru, 2015). 
Untuk menikmati amping, Orang Melayu Sambas biasanya mencampur amping dengan parutan kelapa yang dicampur gula merah. Selain dengan parutan kelapa biasanya amping dihidangkan dengan cara dimasukan ke dalam air gula. Pada saat ngamping biasanya orang Melayu Sambas berkumpul di dalam masjid dan masing-masing orang membawa amping yang telah mereka buat untuk dimakan bersama. Sebelumnya, seorang pak labai (tokoh agama di masyarakat), terlebih dahulu membacakan doa selamat pada air yang telah dibawa petani yang akan siram pada benih padi yang akan ditanam atau disemai. Pada saat ngamping ini, orang Melayu Sambas biasanya bertukar pikiran atau pengetahuan tentang bercocok tanam. ${ }^{22}$

\section{Belalek}

Belalek maksudnya adalah bergotong royong. Belalek ini salah satu wujud dari rasa kebersamaan atau rasa kekeluargaan. Belalek telah ada sejak dulu di Sambas, di mana seseorang punya kewajiban membantu dan punya hak dibantu sesamanya. Belalek diperlukan orang Melayu Sambas terutama pada saat musim tanam tiba. Berdasarkan hasil wawancara pada sejumlah informan di lapangan, kaum perempuan biasanya menjelang menggarap sawah, mengajak kerabat atau tetangga yang juga memiliki sawah atau ladang untuk bekerja sama dan saling bantu-membantu, mulai dari proses menanam padi (nandor), merumput, sampai saat musim panen tiba (beranyi'). Jumlah orang yang diajak bekerjasama tidak mesti, tergantung kesepakatan, dalam pengertian satu sama lain sudah samasama sanggup untuk saling bantu menggarap sawah mereka masingmasing secara bergiliran. ${ }^{23}$

Pada prinsipnya, belalek di Sambas hampir mirip dengan arisan. Bedanya dari bentuk kegiatan saja. Biasanya orang Melayu Sambas, melakukannya pada saat siang hari sampai sore hari sesuai jarak yang mereka tempuh dari rumah ke sawah. Belalek tetap

${ }^{22}$ Berdasarkan informasi dari hasil wawancara dengan Bapak Ramlan dan Ibu Maniah, orang Melayu Sambas, 19 Juli 2018 di Sambas.

${ }^{23}$ Berdasarkan informasi dari hasil wawancara dengan Bapak Hamid, Ibu Susi dan ibu Naimah, orang Melayu Sambas, 21-22 Juli 2018 di Sambas. 
dilakukan, meski cuaca sedang tidak cerah, seperti hujan atau panas terik. Kecuali pada saat cuaca ekstrim, yang tidak memungkinkan seseorang melakukan pekerjaans bertani padi. ${ }^{24}$

Melalui belalek solidaritas dan keharmonisan hidup bermasyarakat terpelihara. Ketika bertani padi, sejauh yang peneliti amati mereka tidak lupa untuk saling bahagia, bercengkerama satu dengan yang lain, dan bersenda gurau. Salah satu alasan, bertani padi dilakukan secara belalek adalah untuk menyelesaikan suatu pekerjaan dari bertani padi sehingga lebih cepat selesai. Hal ini berkaitan dengan masalah waktu. Jadi, secara pragmatis, petani padi di Sambas memiliki efisiensi waktu yang tinggi.

Menariknya, yang paling berperan dalam belalek adalah kaum perempuan. Fakta sosial ini, dalam pengertian yang bisa kita pinjam dari Emile Durkheim ${ }^{25}$, menunjukkan bahwa perempuan sangat penting dalam kehidupan orang Melayu Sambas. Belalek memberikan ruang seluas-luasnya bagi kaum perempuan untuk bersama-sama bekerja dengan kaum laki-laki. Maka belalek senyatanya telah membuka ruang lebih luas bagi kaum perempuan untuk terlibat bekerja tidak hanya terbatas hanya pada urusan rumah tangga. Di Sambas, fakta sosialnya, seorang perempuan mempunyai dua posisi atau double-status sekaligus dalam "kegiatan bekerja", -- dalam istilahnya Pudjiwati Sayogdjo 22 yaitu dalam pekerjaan rumah tangga (home-work) dan pekerjaan yang menghasilkan pendapatan (langsung) (income earning work). ${ }^{26}$

Belakangan, belalek sudah mulai jarang dilakukan lagi, sehingga memunculkan sistem upah sebagaimana hasil penelitian Wewen Darmawan, Amrazi Zakso, dan Gusti Budjang. ${ }^{27}$

${ }^{24}$ Berdasarkan informasi dari hasil wawancara dengan Bapak Hamid, Ibu Susi dan ibu Naimah, orang Melayu Sambas, 21-22 Juli 2018 di Sambas.

${ }^{25}$ Emile Durkheim and Steven Lukes, The Rules of Sociological Method, 1st American ed (New York: Free Press, 1982).

${ }^{26}$ Pudjiwati Sajogyo, Peranan Wanita Dalam Perkembangan Masyarakat Desa. (Jakarta: Rajawali, 1983), 22.

${ }^{27}$ Wewen Darmawan, Amrazi Zakso, Gusti Budjang, "Memudarnya NilaiNilai Budaya ‘Belalek’ Dalam Bidang Pertanian Pada Masyarakat Pedesaan.” 


\section{Makan Beras Baru}

Makan beras baru, diadakan setelah beranyi, oleh orangorang yang memperoleh hasil panen bagus. Makan beras baru yang oleh sebagian orang Melayu juga disebut dengan sedekah nasi ini, dilaksanakan sebagai bentuk ungkapan syukur pada Tuhan. ${ }^{28}$ Harapannya, Tuhan tidak mencabut rezeki panen padi pada beranyi berikutnya. Orang-orang yang diundang oleh yang berhajat mengadakan beranyi, adalah kalangan keluarga, tetangga, tokoh masyarakat, tokoh agama, dan pak labai. Undangan disampaikan dengan cara nyarro'. Nyarro' berasal dari kata saro' dalam bahasa Sambas yang berarti memanggil, dalam pengertian mengundang orang datang menghadiri hajatan yang punya hajat, seperti makan beras baru. Cara nyarro' dilakukan dengan mendatangi setiap rumah orang yang diundang untuk menghadiri hajatan. ${ }^{29}$

Makan beras baru yang dimulai jam 10.00 WIB. Orang yang diundang menghadiri makan beras baru tidak perlu membawa beras dan uang seperti yang biasa ditemui pada pelaksanaan acara lainnya di Sambas. Setelah tamu yang diundang baik tetangga dan keluarga berkumpul, maka pak labai memimpin pembacaan doa. Setelah pembacaan doa, makanan dihidangkan untuk dicicipi oleh para undangan. Menu utamanya adalah nasi dari beras yang baru dipanen, dengan lauk pauk, yang biasanya dihidangkan sebanyak 6 macam. Macamnya tergantung yang punya hajat. Dalam menyiapkan makan beras baru, tetangga biasanya ikut membantu pihak keluarga yang berhajat, seperti memasak nasi atau lauk bagi perempuan, dan menggelar tarup atau tikar bagi laki-laki. ${ }^{30}$

\section{Makan Bersama di Sawah}

Makan bersama dilakukan sesaat setelah menyelesikan pekerjaan bertani padi. Makan bersama dilakukan dengan tujuan

${ }^{28}$ Berdasarkan informasi dari hasil wawancara dengan Bapak Ramlan dan Ibu Maniah, orang Melayu Sambas, 19 Juli 2018 di Sambas.

${ }^{29}$ Berdasarkan informasi dari hasil wawancara dengan Ibu Latifah, orang Melayu Sambas, 21 Juli 2018 di Sambas.

${ }^{30}$ Berdasarkan informasi dari hasil wawancara dengan Bapak Hamid, Ibu Susi, Ibu Latifah, dan ibu Naimah, orang Melayu Sambas, 21-22 Juli 2018 di Sambas. 
memberi makan pada orang yang membantu bertani padi, baik mereka yang diupah untuk membantu atau mereka yang membantu karena maksud belalek. Pelaksanaan makan bersama bisa pagi hari atau siang hari. Jika pagi hari, maka makan bersama dilakukan pada pukul $10.00 \mathrm{WIB}$, karena perkiraan selesainya petani bertani padi sekitar pukul 10.00 WIB. Sedangkan untuk siangnya, dilakukan pada jam pulang yaitu sore pukul 17.00 WIB. Saat mendekati jam pulang, pemilik sawah biasanya lansung menghidangkan makanan untuk dicicipi secara bersama-sama, baik bagi pemilik sawah maupun orang yang membantu. Tidak ada ketentuan makanan apa yang dihidangkan. Macamnya disesuaikan dengan kemampuan yang menghidangkan makanan. Selain untuk menghilangkan rasa lelah dan lapar setelah bertani padi, makan bersama di sawah juga dimanfaatkan untuk bertukar pikiran. ${ }^{31}$

\section{Persatuan Padi}

Persatuan Padi adalah istilah orang Melayu Sambas untuk semacam arisan padi. Arisan padi dilakukan setelah selesai panen atau beranyi. Banyaknya padi yang ditetapkan dalam arisan padi tidak dibatasi, bergantung dari kemampuan orang yang mengikuti arisan padi. Begitu pula orang yang menerima arisan, mesti membayar padi sebanyak yang diterima setelah selesai beranyi. Pada prinsipnya persatuan padi dianggap sangat membantu orang Melayu Sambas, karena dianggap sangat mendukung dari segi ekonomi. ${ }^{32}$

Inti dari Persatuan Padi adalah untuk mempererat hubungan antar petani. Selain itu, saling membantu sesama adalah alasan dari arisan padi. Bisa jadi orang yang membayar arisan padi pada beranyi musim ini, pada beranyi berikutnya mendapatkan hasil

${ }^{31}$ Berdasarkan informasi dari hasil wawancara dengan Bapak Hamid, Ibu Susi, Ibu Latifah, dan ibu Naimah, orang Melayu Sambas, 21-22 Juli 2018 di Sambas.

${ }^{32}$ Berdasarkan informasi dari hasil wawancara dengan Bapak Hamid, Ibu Susi, Ibu Latifah, dan ibu Naimah, orang Melayu Sambas, 21-22 Juli 2018 di Sambas. 
panen yang kurang atau bahkan gagal panen. Sehingga persatuan padi bisa ikut membantu mereka, terutama secara ekonomi. ${ }^{33}$

\section{Pantang Larang dalam Bertani padi}

Orang Melayu Sambas mengenal pantang larang, sebagai bagian dari bentuk kearifan lokal mereka sebagai Melayu dan Muslim. Pantang larang adalah perintah-perintah atau aturan-aturan yang tidak tertulis di masyarakat yang melarang suatu perbuatan untuk dilakukan, atau sesuatu yang terlarang (dilarang untuk dilakukan) karena dipandang keramat atau suci dari nenek moyang yang harus diamalkan demi mencapai kehidupan yang sempurna. Kepercayaan yang berlaku di kalangan orang Melayu Sambas, jika pantangan atau larangan dilanggar, dapat menimbulkan bala' atau musibah. Kepercayaan orang Melayu Sambas pada pantang larang ini diungkap dalam penelitian Syamsul Kurniawan. ${ }^{34}$

Dalam bertani padi, orang Melayu Sambas tidak diperbolehkan membakar sisa batang padi atau yang disebut dengan Rapun. Berdasarkan wawancara pada sejumlah informan, sisa batang padi atau rapun, tidak diperbolehkan dibakar, terutama karena pada sisa batang padi atau rapun, melekat padanya bacaan doa-doa yang dikutip dari Al-Quran atau serapahan, sehingga membakarnya berarti membakar khasiat doa atau serapahan tersebut. Sehingga dikhawatirkan, pada saat beranyi, hasil panen padi kurang menggembirakan bahkan dikhawatirkan gagal panen. ${ }^{35}$

${ }^{33}$ Berdasarkan informasi dari hasil wawancara dengan Bapak Hamid, Ibu Susi, Ibu Latifah, dan ibu Naimah, orang Melayu Sambas, 21-22 Juli 2018 di Sambas.

${ }^{34}$ Syamsul Kurniawan, "Pantang Larang in The Sepinggan Village Muslim Community from The Perspective of Character Education," Ta'dib 21, no. 2 (December 31, 2016): 113, https://doi.org/10.19109/td.v21i2.771; Syamsul Kurniawan, "Pantang Larang And The Environmental Wisdom Of Sambasness Malay In The Sepinggan Village," KALAM 12, no. 1 (July 3, 2018): 87, https://doi.org/10.24042/klm.v12i1.1882.

${ }^{35}$ Berdasarkan informasi dari hasil wawancara dengan Iyus, Amal, dan Bapak Rabuli, orang Melayu Sambas, 21-22 Juli 2018 di Sambas. 


\section{E. Bertani Padi Dan Nilai-Nilai Islam}

Secara umum, bertani padi oleh orang Melayu Sambas membangun etos kerja. Etos kerja ini muncul sebagai sikap atas kehendak dan kesadaran sendiri yang didasari oleh sistem orientasi nilai budaya terhadap kerja. Bertani padi juga membangun tanggung jawab. Seperti sewa lahan untuk dipakai bertanam padi, mereka yang menyewa, dibebankan tanggung jawab untuk merawat sawah yang disewa, bukan hanya sekedar untuk mengambil untung dari menanam padi.

Pada ngamping, makan beras baru, dan makan bersama di sawah, nilai positif yang dibangun adalah nilai religius, yaitu bersyukur. Orang-orang yang bersyukur dengan totalitas akan didorong untuk menjadi pribadi yang ikhlas, sabar, bersahaja, tidak mudah untuk menyalahkan Tuhan, murah hati, merasa berkecukupan, tidak materialistis, dan selalu berpikiran positif. ${ }^{36}$ Pada ngamping, makan beras baru, dan makan bersama di sawah juga membangun kepedulian. Dengan kepedulian, seseorang memiliki kemampuan untuk berempati kepada orang lain dan menjalani hidup berdasarkan rasa kasih sayang, cinta kasih, dan belas kasih kepada orang-orang di sekitarnya. Kepedulian berarti bersedia mendengarkan dan mengerti saat seseorang membutuhkan bantuan.

Bertani padi beserta kearifan lokalnya ini mencerminkan nilai-nilai Islam, seperti etos kerja (Qs Al-Mujadilah ayat 11; Qs. AlJumu'ah ayat 9-10), tanggung jawab (Qs. An-Naml ayat 18; Qs. AshShaffat ayat 22, 23, 24,102; Qs. Al-Mudatstsir ayat 38; Qs. AlAn'am ayat 164; Qs. An-Nahl ayat 25; Qs. Yaasiin ayat 12), tolong menolong (Qs Al-Maidah ayat 20); pandai bersyukur (Qs. AlBaqarah ayat 152; Qs. Ibrahim ayat 7; Qs. Luqman ayat 12; Qs. AlAnfal ayat 26; Qs. An-Nahl ayat 78; Qs. Al-Ankabut ayat 17; Qs. AlA'raf ayat 10; Qs.Al-Furqan ayat 62; Qs. Al-Baqarah ayat 172; Qs. Al-Baqarah ayat 239; Qs. Ali Imran ayat 123, 144, 145; Qs. AlMaidah ayat 6, 89; Qs. Al-A'raf ayat 58, 144, 189; Qs. An-Nahl ayat 121; Qs. Al-Jatsiyah ayat 12; Qs. Al-Waqiah ayat 70; Qs. Al-Mulk

383.

${ }^{36}$ Ida Fitri Shobihah, “Kebersyukuran,” Jurnal Dakwah 15, no. 2 (2014): 
ayat 23; Qs. Al-Insan ayat 3; Qs. An-Naml ayat 40; Qs. Al-Qasas ayat 73; Qs. Saba ayat 13; Qs. Az-Zumar ayat 66; Qs. Al-Baqarah ayat 52, 56, 185, 243; Qs. Al-An'am ayat 53, 63; Qs. Al-A'raf ayat 17; Qs. Ibrahim ayat 5; Qs. An-Nahl ayat 14; Qs. Al-Mukminun ayat 78; Qs. Ar-Rum ayat 46; Qs. Luqman ayat 31; Qs. As-Sajdah ayat 9; Qs. Fathir ayat 12; Qs. Yaasiin ayat 35, 73; Qs. Al-Mukmin ayat 61), ikhlas (Qs. Al-A'raf ayat 29; Qs.Shad ayat 82-83; Qs. Az-Zumar ayat 2, 3, 11; Qs. Al-Hijr ayat 39-40; Qs. Al-Mu'min ayat 14, 65; Qs. AlBayyinah ayat 5), sabar (Qs. Ar-Ra'd ayat 22; Qs. Ali 'Imran ayat 120, 146, 186, 200; Qs. An-Nahl ayat 126; Qs. Al-Baqarah ayat 155156; Qs. Al-Furqan ayat 75; Qs. Thaha ayat 132; Qs. Al-Ahqaf ayat 35; Qs. Al-Anfal ayat 46; Qs. Al-Ashr ayat 2, 3; Qs. Al-Baqarah ayat 156, 157; Qs. Muhammad ayat 31; Qs. Al-Insan ayat 23, 24; Qs. AlBaqarah ayat 177, 249; Qs. An-Nisa' ayat 19, 25; Qs. Al-An'am ayat 34; Qs. Al-A'raf ayat 87, 137; Qs Al-Anfal ayat 65; Qs. Hud ayat 49), kedermawanan (Qs Al-Isra' ayat 26, 27, 29, 30; Qs. Ali Imran ayat 180), cinta kasih (Qs. Al-Fatihah ayat 1; Qs. Al-Baqarah ayat 160, 163, Qs. An-Naml ayat 30, Qs. Ali Imran ayat 14, 31; Qs. AzZukhruf ayat 67, Qs. Ar-Ruum ayat 21, Qs. Al-Mumtahanah ayat 7, Qs. Maryam ayat 96, Qs. Al-Anbiya ayat 83, Qs. Al-Maidah ayat 74, Qs. An-Nisa' ayat 110, Qs. At-Taubah ayat 104), kepedulian (Qs. Ali Imran ayat 103, 104, 133, 134, 135,159; Qs. An-Nisa' ayat 86, Qs. Al-Hujurat ayat 10, 11, 12, 13; Qs. Al-Anfal ayat 1), dan lain-lain.

\section{F. Bertani Padi Beserta Kearifan Lokalnya Dapat Membangun Karakter}

Menurut Pat Duffy Hutcheon, budaya punya kekuatan dalam membangun karakter, ${ }^{37}$ atau pada artikel ini kita sebut dengan kepribadian. Demikian pula pada bertani padi orang Melayu Sambas, yang sejauh peneliti amati, mengandung nilai-nilai positif yang dekat dengan ajaran Islam, sehingga punya pengaruh dalam membangun karakter.

Praeger, 1999).

${ }^{37}$ Pat Duffy Hutcheon, Building Character and Culture (Westport, Conn: 
Kecenderungan ini mudah dipahami, mengingat manusia dalam kehidupannya, sulit untuk lepas dari pengaruh ajaran agama yang mereka anut. Namun karena manusia juga sebagai makhluk sosial, sehingga pengaruh tradisi lokal dan atau adat budaya tempat mereka tinggal, pada gilirannya mewarnai perjalanan kehidupannya dari masa ke masa yang melembaga dalam kearifan lokal mereka, sebagai ujud dari persentuhan yang kita sebut dengan akulturasi.

Menurut Koentjaraningrat, akulturasi itu sendiri muncul bila suatu kelompok masyarakat dengan suatu kearifan lokal tertentu dihadapkan dengan unsur-unsur asing yang berbeda, unsur-unsur asing itu lambat laun diterima dan diolah ke dalam kearifan lokal sendiri tanpa menyebabkan hilangnya kepribadian kearifan lokal itu sendiri. ${ }^{38}$ Pada saat nilai agama bersentuhan dengan kearifan lokal, maka bisa terjadi kesesuaian, atau tidak menutup kemungkinan yang terjadi sebaliknya, saling berbenturan satu sama yang lain, walau pada kasus ini sangat jarang terjadi.

\section{Bagan 1.}

Hubungan Islam dan Kearifan Lokal

Pada Bertani padi Orang Melayu Sambas

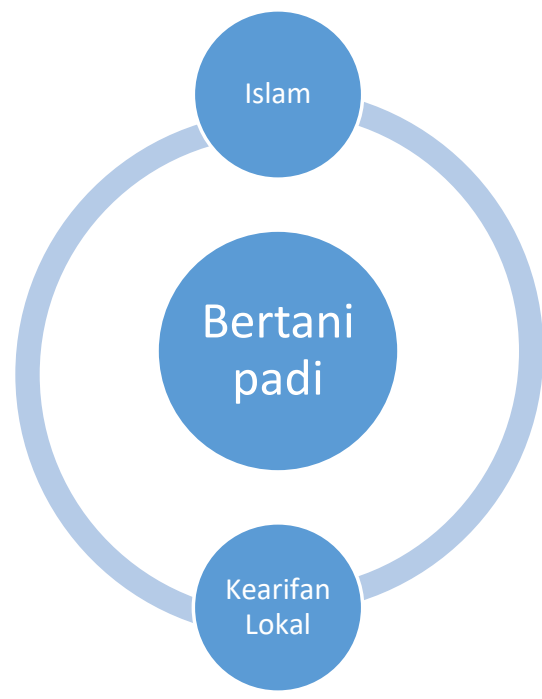

${ }^{38}$ Koentjaraningrat, Pengantar Antropologi (Jakarta: Aksara Baru, 1974), 152. 
Di Sambas, nilai-nilai positif dalam ajaran Islam bersentuhan dengan kearifan lokal dan melingkari aktifitas bertani padi yang dilakukan orang Melayu Sambas (sebagaimana bagan 1 di atas), sehingga nilai-nilai tersebut melekat pada identitas mereka, penanda mereka sebagai bagian dari komunitas Melayu yang bermartabat dan sekaligus muslim yang taat. Inilah mengapa, pekerjaan bertani padi beserta kearifan lokalnya representatif dalam membangun karakter.

\section{G. Simpulan}

Kearifan lokal orang melayu Sambas yang berupa gagasangagasan setempat yang bersikap bijaksana, penuh kearifan, bernilai baik yang tertanam dan diikuti, hakikatnya dapat membangun karakter. Bertani padi adalah salah satu bentuk kearifan lokal orang Melayu Sambas, yang mempunyai peran sangat strategis dalam membangun karakter masyarakat, khususnya petani padi. Nilai-nilai dalam kearifan lokal bertani padi yang dianut oleh orang Melayu Sambas akan menjadi identitas bagi mereka, penanda mereka sebagai bagian dari komunitas masyarakat yang bermartabat.

Di Sambas, bertani padi dilakukan secara tradisional. Ketradisionalan ini, nampak dari kebiasaan-kebiasaan bertani padi oleh orang Melayu Sambas dan telah berlangsung sangat lama serta turun-temurun. Keberlangsungan bertani padi yang mencerminkan kearifan lokal orang Melayu Sambas, tercermin dari nilai-nilai yang berlaku dalam kelompok mereka. Nilai-nilai itu menjadi pegangan mereka, dan menjadi bagian dari kehidupan yang tak terpisahkan, baik sikap atau perilaku mereka sehari-hari

Secara umum, bertani padi oleh orang Melayu Sambas membangun etos kerja. Etos kerja ini muncul sebagai sikap atas kehendak dan kesadaran sendiri yang didasari oleh sistem orientasi nilai budaya terhadap kerja. Bertani padi juga membangun tanggung jawab. Sementara pada ngamping, makan beras baru, dan makan bersama di sawah, nilai positif yang dibangun adalah nilai religius, yaitu bersyukur dan kepedulian. Bersyukur mendorong untuk menjadi pribadi yang ikhlas, sabar, bersahaja, tidak mudah untuk menyalahkan Tuhan, murah hati, merasa berkecukupan, tidak 
materialistis, dan selalu berpikiran positif. Sementara dengan kepedulian sosial, seseorang memiliki kemampuan untuk berempati kepada orang lain dan menjalani hidup berdasarkan rasa kasih sayang, cinta kasih, dan belas kasih kepada orang-orang di sekitarnya.

Bertani padi adalah salah satu bentuk kearifan lokal orang Melayu Sambas, yang dekat dengan nilai-nilai Islam, seperti etos kerja, tanggung jawab, tolong menolong, pandai bersyukur, sabar, kedermawanan, cinta kasih, kepedulian, dan lain-lain.

Di Sambas, nilai-nilai positif dalam ajaran Islam bersentuhan dengan kearifan lokal dan melingkari aktifitas bertani padi yang dilakukan orang Melayu Sambas, sehingga nilai-nilai tersebut melekat pada identitas mereka, penanda mereka sebagai bagian dari komunitas Melayu yang bermartabat dan sekaligus muslim yang taat. Inilah mengapa, pekerjaan bertani padi beserta kearifan lokalnya representatif dalam membangun karakter. [.]

\section{DAFTAR PUSTAKA}

Badan Pusat Statistik Kabupaten Sambas. "Publikasi Statistik." Badan Pusat Statistik Kabupaten Sambas (blog), 2018. https://sambaskab.bps.go.id/.

Dahnke, Gordon L., and Glen W. Clatterbuck, eds. Human Communication: Theory and Research. Belmont, Calif: Wadsworth Pub. Co, 1990.

Durkheim, Emile, and Steven Lukes. The Rules of Sociological Method. 1st American ed. New York: Free Press, 1982.

Fah. "Luas Sawah Di Sambas Potensi Hasilkan 169.465 Ton Padi." Pontianak Post. Pebruari 2018.

Hamdan Darsani. "Hairiah: Sambas Merupakan Lumbung Beras Kalbar.” Tribun Pontianak. September 19, 2016.

Hatamar Rasyid. "Nilai-Nilai Kearifan Lokal Dalam Pengembangan Pendidikan Karakter Di Era Global.” Edugama 1, no. 1 (2015): 1-31. 
Hermansyah. Islam Dan Melayu Di Borneo. Pontianak: IAIN Pontianak Press, 2015.

Hutcheon, Pat Duffy. Building Character and Culture. Westport, Conn: Praeger, 1999.

Ida Fitri Shobihah. "Kebersyukuran." Jurnal Dakwah 15, no. 2 (2014): 383-406.

Koentjaraningrat. Pengantar Antropologi. Jakarta: Aksara Baru, 1974.

Kurniawan, Syamsul. "Pantang Larang And The Environmental Wisdom Of Sambasness Malay In The Sepinggan Village." Kalam 12, no. 1 (July 3, 2018): 87. https://doi.org/10.24042/klm.v12i1.1882.

. "Pantang Larang in The Sepinggan Village Muslim Community from The Perspective of Character Education." Ta'dib 21, no. 2 (December 31, 2016): 113. https://doi.org/10.19109/td.v21i2.771.

"Peta Kabupaten Sambas Kalimantan Barat," 2018. https://www.google.com/maps/place/Kabupaten+Sambas,+Kalimant an+Barat/@1.4876623,108.7686435,9z/data=!3m1!4b1!4m5!3m4!1s 0x31e4c6f5a0740299:0x6c63ef7cfcd2b27c!8m2!3d1.3625191!4d109 .2831531 .

Pudjiwati Sajogyo. Peranan Wanita Dalam Perkembangan Masyarakat Desa. Jakarta: Rajawali, 1983.

Rizal Mustansyir. Kearifan Lokal Masyarakat Melayu Sambas Dalam Tinjauan Filosofis. Yogyakarta: Fakultas Filsafat UGM, 2015.

Syamsul Kurniawan, ed. "Tradisi Ngamping Orang Melayu Sambas Desa Sebayan.” In Tradisi dan Kepercayaan Umat Islam di Kalimantan Barat. 1. Yogyakarta: Samudera Biru, 2015.

Syarifuddin Jurdi. Sosiologi Islam Elaborasi Pemikiran Sosial Ibn Khaldun. Yogyakarta: Sukses Offset, 2008.

Wewen Darmawan, Amrazi Zakso, Gusti Budjang. "Memudarnya Nilai-Nilai Budaya 'Belalek' Dalam Bidang Pertanian Pada Masyarakat Pedesaan." Jurnal Pendidikan Dan Pembelajaran 5, no. 3 (2016): 1-14. 